\title{
INDUKSI KALUS DARI BEBERAPA KULTIVAR TANAMAN KENTANG (Solanum tuberosum L.) DATARAN MEDIUM SECARA IN VITRO MENGGUNAKAN VARIASI KONSENTRASI 2,4-D
}

\author{
${ }^{1}$ Sepdian Luri Asmono, ${ }^{2}$ Vega Kartika Sari \\ 1) Program Studi Budidaya Tanaman Perkebunan, ${ }^{2)}$ Program Studi Budidaya Tanaman Hortikultura Jurusan \\ Produksi Pertanian Politeknik Negeri Jember \\ Jalan Mastrip Kotak Pos 164 Jember \\ sepdianluri@gmail.com
}

\begin{abstract}
This study aims to determine the concentration of 2,4-D to grow a callus on several potato medium cultivars such as DTO-28 and Desiree. This study uses a completely randomized design factorial. Factors to be tested is the concentration of 2,4-D: 4.53; 9.05; 13.58; $18.10 \mu \mathrm{M}$ and Potato Cultivar: DTO-28 and Desiree. There are a total of 8 treatments with 5 replications. Parameters measured include the time appeared callus, callus fresh weight, percentage of callus formation, as well as the morphology of callus kualitif parameters, such as texture, color, type of callus, the number of shoots and roots. Data observation of callus morphology presented descriptively, while other data were analyzed by analysis of variance (ANOVA). To know the difference between the treatment performed DMRT at 5\% level. The results of the study, demonstrate that all explants of cultivar Desiree and DTO-28 capable to forming callus, with watery crumb texture and average white and yellowish green. DTO-28 cultivars are more responsive to 2,4-D because emerge faster callus which 5 DAP. Both cultivars tested were able to produce callus heaviest at $18.10 \mu \mathrm{M}$ concentrations of 2,4D. From these results it can be concluded that the concentration of $18.10 \mu \mathrm{M}$ concentrations of $2,4-\mathrm{D}$ is the best in spurring the growth of callus potatoes DTO-28 and Desiree.
\end{abstract}

Key words : Potato, In Vitro, callus, 2,4-D

Abstrak
Penelitian ini bertujuan untuk mengetahui konsentrasi 2,4-D yang tepat untuk menumbuhkan kalus pada beberapa kultivar tanaman kentang dataran medium seperti DTO-28 dan Desiree. Penelitian ini menggunakan Rancangan Acak Lengkap faktorial. Faktor yang dicoba adalah konsentrasi 2,4-D: 4,53; 9,05; 13,58; 18,10 $\mu \mathrm{M}$ dan Kultivar Kentang: DTO-28 dan Desiree. Terdapat total 8 perlakuan dengan 5 kali ulangan. Parameter yang diukur meliputi saat muncul kalus, berat segar kalus, persentase terbentuknya kalus, serta parameter kualitif terhadap morfologi kalus, seperti tekstur, warna, jenis kalus, jumlah tunas dan akar. Data hasil pengamatan terhadap morfologi kalus disajikan secara deskriptif, sedangkan data yang lain dianalisis dengan analisis ragam (ANOVA). Untuk mengetahui perbedaan antara perlakuan dilakukan uji DMRT pada taraf 5\%.Hasil penelitian (33 HST) menunjukkan bahwa semua semua eksplan dari Kultivar DTO-28 dan Desiree mampu membentuk kalus, dengan tekstur remah berair dan rata-rata berwarna putih dan hijau kekuningan. Kultivar DTO-28 lebih responsif terhadap ZPT 2,4-D dan mampu memunculkan kalus lebih cepat yaitu pada 5 HST. Kedua kultivar yang diujikan mampu menghasilkan kalus terberat pada konsentrasi 18,10 $\mu \mathrm{M}$ 2,4-D.Dari hasil tersebut dapat disimpulkan bahwa konsentrasi 18,10 $\mu \mathrm{M}$ 2,4-D merupakan konsentrasi terbaik dalam memacu pertumbuhan kalus kentang DTO-28 dan Desiree.

Kata Kunci :Kentang, In Vitro, kalus, 2,4-D

\section{PENDAHULUAN}

Kebutuhan kentang di dalam negeri semakin meningkat. Upaya pemenuhan kentang, memerlukan adanya pengembangan di dataran medium (300-700 mdpl). Di Indonesia ada beberapa kentang dataran medium yang juga telah dikembangkan dan memiliki produksi yang tinggi diantaranya adalah Kultivar Desiree, Cipanas, Aquilla, DTO-28 dan DTO-33 (Prasetyo dan
Sastrahidayat, 2004; Prabaningrum et al., 2014; Aulia et al., 2014; Rustianingsih 2000; Sari, 2015).

Pengembangan kentang dataran medium juga sangat potensial meningkatkan pendapatan petani, karena memungkinkan untuk ditanam bergiliran dengan tanaman padi (Basuki et al., 2009).

Ketersediaan bibit dari varietas unggul dataran medium juga merupakan aspek penting yang harus diperhatikan dalam mendukung pengembangan tersebut. Saat ini teknik kultur 
jaringan merupakan teknik yang direkomendasikan pemerintah untuk memproduksi benih unggul kentang. Melalui teknik ini benih dapat dihasilkan dalam jumlah banyak dengan waktu relatif singkat, dan tidak tergantung pada iklim dan musim, serta bebas virus (Yusnita, 2003; Gunawan, 1992).

Metode kultur jaringan tanaman yang dapat digunakan untuk produksi bibit kentang salah satunya melalui induksi kalus. Kalus ketang dapat diinduksi dengan menggunakan Zat Pengatur Tumbuh (ZPT) golongan Auksin yang salah satunya adalah 2,4-Dichlorofenoxyacetic acid (2,4D) (Al-Husaini et al., 2015; Solim dan Harahap, 2014; Sherkar and Chavan, 2014).

Penelitian ini bertujuan untuk mengetahui konsentrasi 2,4-D yang tepat untuk menumbuhkan kalus tanaman kentang dataran medium seperti Kultivar DTO-28 (Solanum tuberosum L. cv. DTO-28) dan Desiree (Solanum tuberosum L. cv. Desiree).

\section{METODOLOGI PENELITIAN}

Penelitian ini dilaksanakan di Laboratorium Kultur Jaringan tanaman Politeknik Negeri Jember dari dari Bulan September-November 2016.

Peralatan yang akan digunakan antara lain peralatan diseksi, cawan petri, Laminar Air Flow Cabinet (LAFC), autoklaf, $\mathrm{pH}$ meter, petridish, erlenmeyer, gelas ukur, lampu bunsen, timbangan digital, timbangan analitik, hot plate \&magnetic stirrer, pipet mikro, gelas ukur, mikroskop dan kamera.

Bahan yang dibutuhkan adalah planlet kentang Kultivar DTO-28 dan Desiree, media MS, ZPT 2,4-D, alkohol 70\% dan 96\%, kertas tisu steril, tissue gulung, akuadest steril, air bersih, spiritus, plastik wrapping, kertas label.

Penelitian ini disusun menggunakan Rancangan Acak Lengkap Faktorial, terdiri dari 4 taraf konsentrasi 2,4-D (4,53; 9,05; 13,58; 18,10 $\mu \mathrm{M}), 2$ taraf kultivar (DTO-28 dan Desiree). Kombinasi perlakuan berjumlah 8 dengan 5 kali ulangan.

Parameter pengamatan meliputi saat muncul kalus yang dilakukan setiap hari, kemudian berat basah kalus, persentase eksplan membentuk kalus, serta parameter kualitif terhadap morfologi kalus (tekstur, warna, jenis kalus) dilakukan pada akhir penelitian (33 HST). Data hasil pengamatan terhadap morfologi kalus disajikan secara deskriptif, sedangkan data saat muncul kalus dan berat basah kalus dianalisis dengan analisis ragam (ANOVA). Untuk mengetahui perbedaan antara perlakuan dilakukan uji DMRT pada taraf 5\%.

Bahan tanam yang digunakan merupakan ruas planlet kentang. Di dalam LAFC, planlet dibuang daun kemudian dipotong setiap ruasnya dengan panjang $1 \mathrm{~cm}$ kemudian ditanamkan pada media perlakuan.

Setiap perlakuan terdiri dari lima ulangan, dan setiap ulangan ada 2 botol. Masing-masing botol terdapat 2 eksplan. Sehingga total eksplan yang digunakan berjumlah 80 eksplan.

Eksplan yang sudah ditanamkan kemudian diinkubasi dalam kondisi gelap untuk memacu pertumbuhan kalus.

\section{HASIL DAN PEMBAHASAN}

\section{Persentase Pembentukan Kalus}

Hasil pengamatan diakhir penelitian (33 HST) yang tertera pada Tabel 1. menunjukkan bahwa keseluruhan eksplan yang ditanam pada 8 kombinasi media perlakuan mampu membentuk kalus dengan persentase $100 \%$. Kalus yang terbentuk mengindikasikan bahwa eksplan yang berasal dari kedua kultivar kentang mampu merespon dengan baik ZPT 2,4-D yang ditambahkan pada media.

Eksplan yang digunakan berupa ruas dari planlet steril yang masih muda. Jaringan dalam ruas tersebut masih bersifat meristematik sehingga proses pembelahan dan pembesaran sel dapat terpacu dengan adanya 2,4-D yang merupakan ZPT golongan auksin. Hal tersebut sesuai dengan hasil penelitian terdahulu bahwa media MS dengan penambahan 2,4-D secara tunggal pada konsentrasi 1 ppm $(4,53 \mu \mathrm{M})-4 \mathrm{ppm}(18,10 \mu \mathrm{M})$ mampu memacu proliferasi kalus tanaman kentang (Abd Elaleemet al., 2009; Khalafallaet al., 2009; Dhaka and Nailwal, 2015; AL-Hussaini et al., 2015; Sherkar and Chavan; 2014; Shahab-ud-din et al., 2011; Laboney et al., 2013; Solim dan Harahap, 2014).

\section{Tekstur Kalus}

Data hasil pengamatan terhadap tekstur kalus pada 33 HST pada Tabel 1., menunjukkan bahwa semua eksplan ruas batang dari Kultivar DTO-28 dan Desiree bertekstur remah dan berair. Eksplan tersebut ditanamkan dalam media MS dengan beberapa konsentrasi 2,4-D, sehingga proses pembelahan sel dapat terpacu dan membentuk tekstur yang remah.

Terbentuknya kalus yang remah disebabkan oleh meningkatnya proses pembelahan sel. ZPT 2,4-D termasuk dalam golongan auksin yang berperan dalam merangsang dan memacu pembelahan dan pembesaran sel, sehingga sel semakin mengalami pertumbuhan tanpa diikuti oleh perkembangan dinding sel kearah penebalan, sehingga tekstur kalus tetap remah. 
Sepdian Luri Asmono, Vega Kartika Sari, Induksi Kalus dari Beberapa Kultivar Tanaman Kentang (Solanum tuberosum L.) Dataran Medium Secara In Vitro Menggunakan Variasi Konsentrasi 2,4-D

Tabel 1. Persentase pembentukan, tekstur, warna dan jenis kalus dari 2 kultivar kentang yang berbeda menggunakan eksplan ruas batang pada beberapa konsentrasi 2,4-D (33 HST).

\begin{tabular}{|c|c|c|c|c|c|c|}
\hline No & Kultivar & $\begin{array}{c}\text { Konsetrasi2, } \\
\text { 4-D } \\
\end{array}$ & $\begin{array}{c}\text { Persentase } \\
\text { Pertumbuhan Kalus }\end{array}$ & Tekstur Kalus & Warna Kalus & Jenis Kalus \\
\hline 1 & \multirow{4}{*}{ DTO-28 } & $4,53 \mu \mathrm{M}$ & $100 \%$ & Remah Berair & Hijau Kekuningan & Non Embrionik \\
\hline 2 & & $9,05 \mu \mathrm{M}$ & $100 \%$ & Remah Berair & Putih Kekuningan & Non Embrionik \\
\hline 3 & & $13,58 \mu \mathrm{M}$ & $100 \%$ & Remah Berair & Hijau Kekuningan & Non Embrionik \\
\hline 4 & & $18,10 \mu \mathrm{M}$ & $100 \%$ & Remah Berair & Hijau Kekuningan & Non Embrionik \\
\hline 5 & \multirow{4}{*}{ Desiree } & $4,53 \mu \mathrm{M}$ & $100 \%$ & Remah Berair & Hijau Kekuningan & Non Embrionik \\
\hline 6 & & $9,05 \mu \mathrm{M}$ & $100 \%$ & Remah Berair & Putih Kekuningan & Non Embrionik \\
\hline 7 & & $13,58 \mu \mathrm{M}$ & $100 \%$ & Remah Berair & Hijau Kekuningan & Non Embrionik \\
\hline 8 & & $18,10 \mu \mathrm{M}$ & $100 \%$ & Remah Berair & Hijau Kekuningan & Non Embrionik \\
\hline
\end{tabular}

Secara visual pada Gambar 1b, kalus yang terbentuk juga berair. Abd Elaleem et al., 2009, juga telah melakukan induksi kalus kentang menggunakan beberapa konsentrasi 2,4-D secara tunggal dan kalus yang terbentuk bertekstur remah dan berair. Kalus remah berair dapat disebabkan Karena sifat auksin yang dapat meningkatkan elastisitas dinding sel, yang menyebabkan air dapat masuk melalui tekanan osmotik sel. Menurut Campbell dan Reece, 2002; Gunawan, 1992 menyatakan bahwa auksin mampu merubah susunan matrix dinding sel sehingga menyebabkan perengganggan dan akibatnya air masuk ke dalam sel, sehingga sel membesar.

\section{Warna Kalus}

Hasil pengamatan secara visual terhadap warna kalus pada akhir pengamatan (33 HST), menunjukkan bahwa rata-rata kalus dari kedua kultivar yang dikulturkan berwarna putih transparan dan hijau kekuningan, seperti pada gambar di bawah ini.
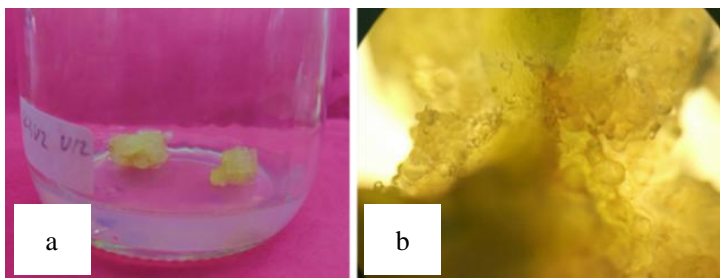

Gambar 1. a) Struktur kalus yang remah dan berair; b) Warna kalus hijau kekuningan transparan dan tidak menunjukkan bentuk nodular embrio.

Warna putih transparan dan hijau kekuningan menunjukkan bahwa kalus masih dalam kondisi yang cukup baik. Warna hijau yang terbentuk pada kalus juga merupakan klorofil yang sudah mulai terbentuk (Andaryani. 2010; Widyastuti, 2000; Rosyidah, et al., 2014). Warna kalus mengindikasikan fase pertumbuhan kalus. Menurut Philip et al, 1995, ada lima fase, yaitu: a) fase lag, sel mulai membelah; b) fase eksponensial, peningkatan laju pembelahan sel pada titik. c) fase Linear, laju pembelahan sel mulai menurun diikuti proses ekspansi sel; d) Fase deselerasi, laju pembelahan dan pembesaran sel meunurun; e) Fase stationer, jumlah dan ukuran sel tetap.

\section{Jenis kalus}

Hasil pengamatan secara visual yang tertera pada Gambar 1b, menunjukkan bahwa jenis kalus yang terbentuk bukan kalus embrionik, karena tidak ditemukan kalus yang berbentuk nodular sebagai penanda perkembangan sel menjadi embrio. Nodul kalus biasanya berwarna putih yang merupakan masa proembrionik, struktur awal terbentuknya embrio Menurut McCown et al. 1988 nodular kalus merupakan perkembangan sel membentuk jaringan-jaringan khusus penyusun embrio, berbentuk bulat dan terpisah-pisah, memiliki struktur yang kompak.

Dari pengamatan yang dilakukan, warna dan tekstur menunjukkan kompetensi untuk berkembang menjadi embrio karena bertekstur remah. Shimizu et al., 1997 menyatakan bahwa kalus yang memiliki struktur remah, berwarna putih dan kekuningan berpotensi menjadi kalus yang embrionik, membentuk embrio somatik.

\section{Saat Muncul Kalus}

Hasil pengamatan terhadap waktu kemunculan kalus tertera pada Tabel 2. Data yang diperoleh menunjukkan bahwa kultivar DTO-28 memberikan respon tercepat dalam memunculkan kalus yaitu rata-rata pada 5,00 HST. Sedangkan Kultivar Desiree rata-rata memunculkan kalus pada 8,55 HST. Perbedaan tersebut dapat terjadi karena faktor genotip yang mempengaruhi respon dalam proses pembentukan kalus.

Perbedaan respon pembentukan kalus tanaman kentang karena faktor genotip sebelumnya telah dilaporkan Hossein and Nikolaevich, 2015. Vinterhalter et al., 2008 menyatakan bahwa kemampuan pembentukan kalus dan morfogenesis 
Tabel 2. Rerata waktu muncul kalus dari kultivar DTO-28 dan Desiree pada beberapa konsentrasi 2,4-D

\begin{tabular}{|c|c|c|c|c|c|c|c|c|}
\hline \multirow{3}{*}{$\begin{array}{c}\text { Kultivar } \\
\text { DTO-28 } \\
\end{array}$} & \multicolumn{6}{|c|}{ Konsentrasi 2,4-D } & \multirow{2}{*}{\multicolumn{2}{|c|}{ Rerata }} \\
\hline & $4,53 \mu \mathrm{M}$ & $9,05 \mu \mathrm{M}$ & & $13,58 \mu \mathrm{M}$ & $18,10 \mu \mathrm{M}$ & & & \\
\hline & $\begin{array}{ll}5,00 \pm 0,00 & \mathrm{a}\end{array}$ & $5,00 \pm 0,00$ & $\mathrm{a}$ & \begin{tabular}{l|l}
$5,00 \pm 0,00$ & $\mathrm{a}$
\end{tabular} & $5,00 \pm 0,00$ & $\mathrm{a}$ & $5,00 \pm 0,00$ & $\mathrm{~A}$ \\
\hline Desiree & $7,20 \pm 1.64 b$ & $7,60 \pm 1.52$ & b & $8,00 \pm 1.00 \mathrm{~b}$ & $11,40 \pm 2.51$ & $\mathrm{c}$ & $8.55 \pm 2.35$ & B \\
\hline Rerata & $6.10 \pm 1.59 \mathrm{~A}$ & $6.30 \pm 1.71$ & A & $6.50 \pm 1.72$ & $8.20 \pm 3.76$ & B & & \\
\hline
\end{tabular}

Keterangan: Angka-angka yang diikuti oleh huruf yang sama berarti tidak berbeda nyata pada taraf uji Duncan 0,05 .

Tabel 3. Rerata berat segar kalus (gr) dari Kultivar DTO-28 dan Desiree pada beberapa konsentrasi 2,4-D

\begin{tabular}{|c|c|c|c|c|c|c|c|c|c|}
\hline \multirow{3}{*}{$\begin{array}{l}\text { Kultivar } \\
\text { DTO-28 } \\
\end{array}$} & \multicolumn{7}{|c|}{ Konsentrasi 2,4-D } & \multicolumn{2}{|l|}{ Rerata } \\
\hline & $4,53 \mu \mathrm{M}$ & $9,05 \mu \mathrm{N}$ & & $13,58 \mu \mathrm{I}$ & & $18,10 \mu$ & & & \\
\hline & $0.33 \pm 0.14 \mathrm{ab}$ & $0.51 \pm 0.18$ & $\mathrm{bc}$ & $0.96 \pm 0.24$ & $\mathrm{~d}$ & $1.56 \pm 0.07$ & $\mathrm{e}$ & $0.84 \pm 0.51$ & $\mathrm{~A}$ \\
\hline Desiree & \begin{tabular}{l|l}
$0.30 \pm 0.11$ & $\mathrm{a}$ \\
\end{tabular} & $0.31 \pm 0.09$ & $\mathrm{a}$ & $0.59 \pm 0.13$ & $\mathrm{c}$ & $0.79 \pm 0.08$ & $\mathrm{~d}$ & $0.50 \pm 0.23$ & B \\
\hline Rerata & $0.31 \pm 0.12 \mathrm{~A}$ & $0.41 \pm 0.17$ & A & $0.77 \pm 0.27$ & B & $1.17 \pm 0.41$ & $\mathrm{C}$ & & \\
\hline
\end{tabular}

Keterangan: Angka-angka yang diikuti oleh huruf yang berarti tidak berbeda nyata pada taraf uji Duncan 0,05 .

tanaman kentang in vitro sangat dipengaruhi oleh faktor genotip.

Ditinjau dari variasi konsentrasi 2,4-D yang digunakan, pada Gambar 2. tertera bahwa rata-rata kalus pertama kali muncul pada konsentrasi 4,53 $\mu \mathrm{M}$ 2,4-D. Hasil tersebut tidak berbeda nyata dengan konsentrasi 9,05 $\mu \mathrm{M}$ dan 13,58 $\mu \mathrm{M}$. Tetapi hasil yang berbeda nyata ditunjukkan pada konsentrasi 2,4-D yang paling tinggi yaitu 18,10 $\mu \mathrm{M}$.

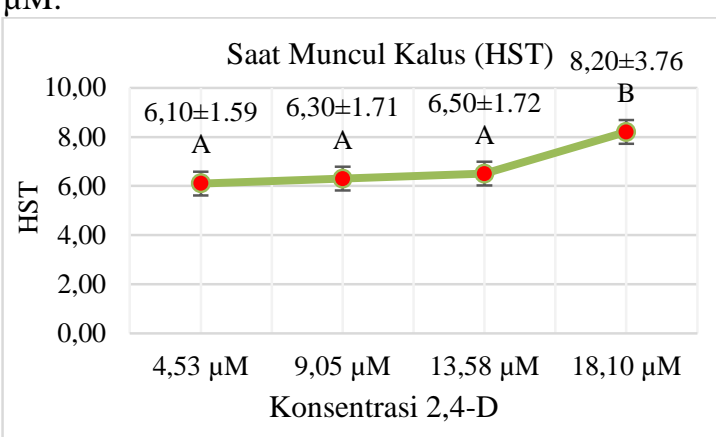

Keterangan: Angka-angka yang diikuti oleh huruf yang sama berarti tidak berbeda nyata pada taraf uji Duncan 0,05 .

Gambar 2. Grafik Rerata Waktu Muncul Kalus pada Variasi Konsentrasi 2,4-D.

Data hasil rerata saat muncul kalus menunjukkan bahwa konsentrasi 2,4-D memberikan pengaruh terhadap waktu kemunculan tunas. Pada konsentrasi 2,4-D yang lebih rendah justru rata-rata waktu kemunculan tunas lebih cepat dibanding konsentrasi yang lebih tinggi. Kemunculan kalus yang lambat dapat disebabkan oleh konsentrasi 2,4-D yang tinggi melebihi konsentrasi optimum, sehingga proses kemunculan eksplan menjadi terhambat. Dalam penelitian ini rata-rata kalus muncul pada 5-12 HST. Rata-rata hasil yang sama juga telah dilaporkan Khalafalla $e t$ al., 2010,bahwa kemunculan kalus kentang yang diinduksi pada konsentrasi 2,0 ppm $(9,05 \mu \mathrm{M})-5,0$ ppm $(22,63 \mu \mathrm{M})$ 2,4-D terlihat mulai dari 7-12 HST.

\section{Berat Segar Kalus}

Berat segar kalus merupakan salah satu parameter untuk mengetahui adanya pertumbuhan masa sel melalui proses pembelahan dan pembesaran sel. Hasil analisis statistik berat segar kalus menunjukkan bahwa adanya pengaruh sangat nyata dari perlakuan variasi kultivar dan konsentrasi 2,4-D. Data hasil uji lanjut Duncan 0,05 tertera pada Tabel 3 .

Kultivar DTO-28 menghasilkan kalus yang lebih berat yaitu rata-rata $0,84 \mathrm{gr}$, dibanding dengan Kultivar Desiree dengan rata-rata 0,50 gr. Perbedaan genotip merupakan penyebab utama perbedaan berat segar kalus yang dihasilkan. Penelitian sebelumnya yang dilakukan ALHussaini et al., 2015, juga mandapati perbedaan berat segar kalus yang dihasilkan dari beberapa varietas ketang yaitu Provento, Burren and Riviera.

Konsentrasi 2,4-D berpengaruh nyata terhadap berat segar kalus (Tabel 3). Kalus yang tumbuh pada konsentrasi 4,53 $\mu \mathrm{M}$ 2,4-D memiliki berat rata-rata terendah, yaitu 0.31 gr. Hasil tersebut tidak berbeda nyata pada perlakuan $9,05 \mu \mathrm{M}$ 2,4-D dengan berat rata-rata 0,41 gr. Perbedaan yang nyata terlihat pada konsentrasi $13,58 \mu \mathrm{M}$ 2,4-D dengan berat rata-rata 0,77 gr. Terjadi peningkatan berat kalus yang tumbuh pada konsentrasi 18,10 $\mu \mathrm{M}$ 2,4-D yaitu $1.17 \mathrm{gr}$.

Semakin tinggi konsentrasi 2,4-D makan terjadi peningkatan pembelahan dan pembesaran sel. Ikeuchi et al., 2013 menyatakan bahwa peningkatan berat segar kalus dapat terjadi karena proses proliferasi sel tanpa disertai diferensiasi.

Peningkatan berat segar kalus juga dipengaruhi oleh pembesaran sel. Hal tersebut terlihat dari pengamatan terhadap tekstur kalus yang remah dan mengandung air. Gunawan, 1992; Campbell dan 
Sepdian Luri Asmono, Vega Kartika Sari, Induksi Kalus dari Beberapa Kultivar Tanaman Kentang (Solanum tuberosum L.) Dataran Medium Secara In Vitro Menggunakan Variasi Konsentrasi 2,4-D

Reece, 2002 menyatakan bahwa auksin menyebabkan pengenduran dinding sel yang mengakibatkan air dapat masuk secara osmosis. Secara mikroskopis sel-sel kalus terlihat transparan dan bentuknya tidak teratur, seperti pada Gambar 3 berikut.
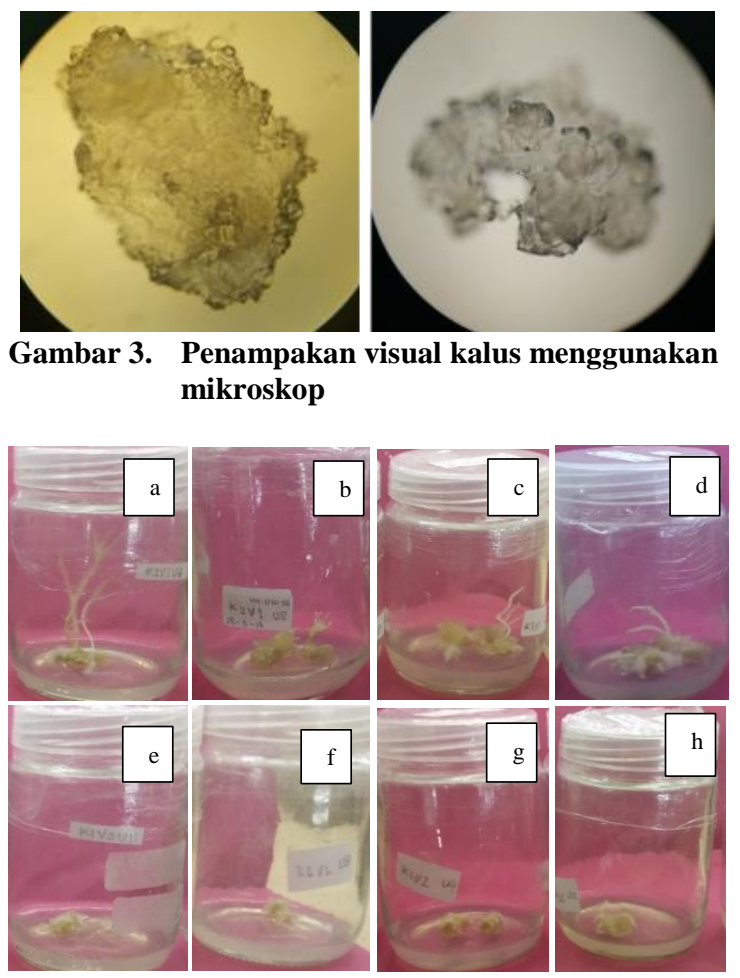

Gambar 4. Pertumbuhan kalus pada 33 HST

a) DTO-28 (4,53 $\mu \mathrm{M} 2,4-\mathrm{D}) \quad$ e)Desiree $(4,53 \mu \mathrm{M} 2,4-\mathrm{D})$

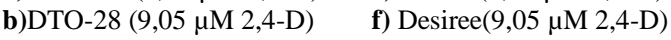

c)DTO-28 (13,58 $\mu \mathrm{M} 2,4-\mathrm{D}) \quad$ g)Desiree $(13,58 \mu \mathrm{M} 2,4-\mathrm{D})$

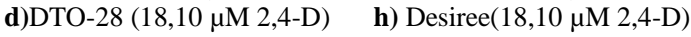

\section{KESIMPULAN}

Berdasarkan hasil penelitian induksi kalus dari Kultivar DTO-28 dan Desiree pada beberapa konsentrasi 2,4-D, maka dapat diambil kesimpulan bahwa, Kultivar DTO-28 lebih responsif terhadap 2,4-D sehingga mampu memunculkan kalus lebih cepat yaitu pada 5 HST dan menghasilkan masa kalus yang lebih berat dibanding Kultivar Desiree. Semakin tinggi konsentrasi 2,4-D maka semakin besar rata-rata berat segar kalus yang dihasilkan. Konsentrasi 18,10 $\mu \mathrm{M} \quad 2,4-\mathrm{D}$ merupakan konsentrasi yang paling baik dalam meningkatkan berat segar kalus dari Kultivar DTO-28 dan Desiree.

Penelitian ini membutuhkan tahap lanjutan terkait variasi somaklonal dengan mengujikan kalus pada mutagen kimia dan kemudian meregenerasi kalus untuk pembentukan tunas kearah mutiplikasi.

\section{UCAPAN TERIMA KASIH}

Penulis mengucapkan terima kasih kepada Pusat Penelitian dan Pengabdian kepada Masyarakat Politeknik Negeri Jember yang telah memberikan kesempatan untuk mengembangkan ilmu pengetahuan melalui kegiatan Penelitian Dosen Pemula Sumber Dana BOPTN.

\section{DAFTAR PUSTAKA}

Abd Elaleem. K, R.S. Modawi and M.M. Khalafalla. 2009. Effect of Plant Growth Regulators on Callus Induction and Plant Regeneration in Tuber Segment Culture of Potato (Solanum tuberosum L.) Cultivar Diamant. African Journal of Biotechnology. 8(11). 25292534.

AL-Hussaini. Z.A., S.H.A. Yousif. and S.A. ALAjeely. 2015. Effect of Different Medium on Callus Induction and Regeneration in Potato Cultivars. International journal of Current Microbiologi and Applied Sciences. 4(5): 856865.

Andaryani. S. 2010. Kajian Penggunaan Berbagai Konsentrasi BAP dan 2,4-D terhadap Induksi Kalus Jarak Pagar (Jatropha curcas L.) secara In Vitro. [Skripsi]. Fakultas Pertanian. Universitas Sebelas Maret. Surakarta.

Aulia. A.N, M. Nawawi, T. Wardiyati. 2014. Uji Daya Hasil Tujuh Klon Tanaman Kentang (Solanum tuberosum L.). Jurnal Produksi Tanaman. 1 (6).

Basuki. R.S., Kusmana. dan E. Sofiari. 2009. Identifikasi Permasalahan dan Peluang Perluasan Area Penanaman Kentang Di Dataran Medium. "Prosiding Seminar Pekan Kentang Nasional Tahun 2008". 20-21 Agustus 2008, Lembang. Vol. 1. Puslitbang Hortikultura, Jakarta. 376-388.

Campbell, N. A. and J. B. Reece. 2002. Biology. Sixth Edition, Pearson Education. Inc. San Francisco. 802-831.

Dhaka, M and T.K.Nailwal. 2015. High efficiency macropropagation of potato (Solanum tuberosum L.) cv. Kufri Jyoti in Kumaun Hills. Journal of Plant Breeding and Crop Science. 7(7): 203-210.

Gunawan. L.W. 1992. Teknik Kultur Jaringan Tumbuhan. Pusat Antar Universitas (PAU) Bioteknologi IPB. Bogor. 
Hossein, P and E.A Nikolaevich. 2015. Statistical Analysis of Growth Factors in Potato During Regeneration with Different Hormonal Treatments. Austrian Journal of Technical and Natural Sciences.

Ikeuchi M, K. Sugimoto, A. Iwase.2013. Plant callus: Mechanisms of Induction and Repression. Plant Cell. 25(9):3159-73.

Khalafalla, M.M, KG. Abd Elaleem and R.S. Modawi. 2010. Callus Formation and Organogenesis of Potato (Solanum tuberosum L.) cultivar Almera. Journal of Phytology. 2(5): 4046

., G. Khadiga, R.S. Modawi, K.G. Abd. Elaleem. 2009. Effect of Plant Growth Regulators on Callus Induction and Plant Regeneration in Tuber Segment Culture of Potato (Solanum tuberosum L.) cultivar Diamant. Afr. J. Biotechnol. 8 (11): 2529-2534.

Laboney. U.Z., G.C. Biswas, M.A. Al-Shoeb. and M.A. Miah. 2013. Callus Induction and Regeneration off Pottato from Shootip Culture. International Journal of Agricultural Sciences. 3 (10): 040-045.

McCown. B., E. Zeldin, H. Pinkalla, and R. Dedolph.1988. NoduleCulture: a Developmental Pathway with High Potencial for Regeneration, Automated Micropropagation, and PlantMetabolite Production from Woody Plants, in GeneticManipulation of Woody Plants, J. Hanover and D. Keathley,Eds., pp. 149-166, Plenum, New York, NY, USA.

Philip, J.D. and K.K. Hampson. 1995. An Assesmant of Morphogenic and Transformation Efficiency in a Range of Varieties of Potato (Solanum tuberosum L.). Euphytica. 85: 101-108.

Prabaningrum. L., T.K. Moekasan, I. Sulastrini, T. Handayani, J.P. Sahat, E. Sofiari. dan N. Gunadi. 2014. Teknologi Budidaya Kentang di Dataran Medium. "Monografi34". Balai Penelitian Tanaman Sayuran Pusat Penelitian dan Pengembangan Hortikultura Badan Penelitian dan Pengembangan Pertanian, Kementerian Pertanian.

Prasetyo. B. dan I.R. Sastrahidayat. 2004. Peningkatan Potensi Produksi Tanaman Kentang (Solanum tuberosum Linn.) di Andisol.Embryo. 1(1).

Rosyidah. M., R. Evi. dan S.R. Yuni. 2014. Induksi Kalus Daun Melati (Jasminum sambac) dengan
Penambahan Berbagai Konsentrasi Dichlorophenoxyacetic acid (2,4-D) dan 6Benzyl Amino Purin (BAP) pada Media MS secara In Vitro.Jurnal Biologi. 3(3): 147-153.

Rustianingsih. R. 2000. Pengujian Klon-Klon kentang (Solanum tuberosum L.) Hasil Silangan Astarte x DTO-28 dan Selfing Astarte.[Skripsi]. Jurusan Budidaya Pertanian. Institut Pertanian Bogor.

Sari. D.C. 2015. Ketahanan Beberapa Klon Kentang (Solanum tuberosum L.) terhadap Fusarium spp. [Tesis].Sekolah Pascasarjana. Institut Pertanian Bogor.

Shahab-ud-din, I.N. Sultan, M.A. Kakar, A. Yousafzai, F.A. Sattar, F. Ahmmad, S.M. Ibrahim, M. Hassanullah. and B. Arif. 2011. The Effects of Different Concentrations and Combinations of Growth Regulators on the Callus Formation of Potato (Solanum tubrosum) Explants. Current Research Journal of Biological Sciences. 3(5): 499-503.

Sherkar H.D and Chavan A.M. 2014. Effect of 2,4D; BAP and TDZ on Callus Induction and Shoot regeneration in Potato. Science Research Reporter. 4(1): 101-105.

Shimizu K, N. Nagaike., T. Yobuya. and T. Edachi. 1997. Plant regeneration from suspension culture of Iris germica. Plant Cell Tiss. Org. Cult. 50: $27-31$.

Solim. M.H. dan F. Harahap. 2014. Induksi Kalus Tanaman Kentang (Solanum tuberosum L.) Varietas Granola dari Jenis Eksplan yang Berbeda dengan Zat Pengatur Tumbuh 2,4-D secara Invitro. "Prosiding Semnas Biologi". 15 Februari 2014, Medan. 190-195.

Vinterhalter D, S. Zdravkovi-Kora, N. Miti, I. Dragicevi, A. Cingel, M. Raspor, and S. Ninkovi. 2008. Protocols for Agrobacterium-mediated Transformation of Potato. In: Texeira de Silva J. (ed.) Fruit, Vegetable and Cereal Science and Biotechnology, Global Science Books.1-15.

Widyastuti. N. 2000. Pelestarian Tanaman Pangan melalui Teknik Kultur In Vitro. J. Teknologi Lingkungan. 1(3): 206-211.

Yusnita. 2003. Kultur Jaringan: Cara Memperbanyak Tanaman Secara Efisien. Agromedia Pustaka. Jakarta. 